\title{
POTENCIAL MOTIVACIONAL DAS APLICAÇÕES MÓVEIS DE APREN- DIZAGEM DE LÍNGUAS ESTRANGEIRAS DUOLINGO E MEMRISE E O SEU USO ENTRE OS ESTUDANTES UNIVERSITÁRIOS NA CROÁCIA \\ MOTIVATIONAL POTENTIAL OF MOBILE FOREIGN LANGUAGE LEARNING APPLI- CATIONS DUOLINGO AND MEMRISE AND THEIR USE AMONG UNIVERSITY STU- DENTS IN CROATIA
}

Predrag Oreški ${ }^{1}$, Vladimir Legac ${ }^{2}$, Krunoslav Mikulan $^{3}$

\author{
PSIQUE • e-ISSN 2183-4806 • VOLUME XV •ISSUE FASCÍCULO 1 \\ 1st JANUARY JANEIRO - 30th JUNE JUNHO 2019 • PP . 9-29 \\ Submited on November 01, 2018 | A ccepted on May 27th (2 rounds of revision) \\ Submetido a 13 de maio, 2019 | A ceite a 26 de maio de 2019 (2 rondas de revisão)
}

\begin{abstract}
Resumo
As Aplicações de aprendizagem de língua móvel, tais como Duolingo e Memrise, permitiram que praticamente todos possam aprender enumeras línguas estrangeiras autonomamente. Este papel é baseado numa pesquisa em opiniões e práticas de estudantes da Faculdade de Formação de Professores da Universidade de Zagreb, na Croácia, que utilizaram as aplicações acima mencionadas para aprender pelo menos uma língua estrangeira. As respostas eram em sua maioria positivas: os entrevistados estavam interessados ou muito interessados em aprender uma língua estrangeira (83.6\%), gostaram da qualidade das aplicações de língua estrangeira (80,1\%), eles aprenderam a usá-los rapidamente ou muito rapidamente (85,4\%), e gostaram também do fato de poderem usar as aplicações, quando e onde querem (77.6\%). Por outro lado, apenas $24 \%$ dos entrevistados concordaram completamente com a instrução que seria capaz de aprender uma língua estrangeira, usando um ou mais desses aplicativos móveis. Uma pesquisa de acompanhamento proposto a fim de abranger outros aplicativos de aprendizagem móvel e para determinar se o alto fator motivacional permaneceria constante, não obstante a natureza repetitiva dos exercícios fornecidos por esses aplicativos.
\end{abstract}

Palavras-chave: Móveis assistida aprendizagem de línguas, Duolingo, Memrise, Motivação

\footnotetext{
${ }^{1}$ University of Zagreb. E-mail: predrag.oreski@ufzg.h.

${ }^{2}$ University of Zagreb. E-mail: vladimir.legac@ufzg.hr.

${ }^{3}$ University of Zagreb. E-mail: krunoslav.mikulan@ufzg.hr.
} 


\begin{abstract}
Mobile language learning applications, such as Duolingo and Memrise, have enabled virtually everyone to autonomously learn numerous foreign languages. This paper is based on a research into opinions and practices of students from the Faculty of Teacher Education of the University of Zagreb in Croatia, who have used the aforementioned applications to learn at least one foreign language. The responses were mostly positive: respondents were very interested or highly interested in learning a foreign language (83.6\%), they liked the gamification quality of the foreign language applications (80.1\%), they learned how to use them quickly or very quickly (85.4\%), and they liked the fact that they can use the applications whenever and wherever they want $(77.6 \%)$. On the other hand, only $24 \%$ of respondents completely agreed with the statement that they would be able tolearn a foreign language using one or more such mobile applications. A follow-up research proposed in order to encompass other mobile learning applications, and to ascertain whether the high motivational factor would remain constant notwithstanding the repetitive nature of the exercises provided by these applications.
\end{abstract}

Key words: Mobile assisted language learning, Duolingo, Memrise, Motivation

\title{
Introduction
}

It is often asserted that information and communication technology are excellent means to motivate students, and motivation is considered as the strongest initiator of knowledge acquisition. According to the motivation theory of Keller and Suzuki (1988, quoted by Alessi \& Trollip, 2004), the learners' motivation is based on four components: attention, relevance, confidence and satisfaction. Another motivation theory by Malone and Lepper (1987, quoted by Alessi \& Trollip, 2004) mentions challenge, curiosity, control and imagination. Alessi and Trollip (2001, p. 165) believe that for successful teaching using multimedia and ICT the following components are important:

- attention (attained by the use of well-designed material and choice of different media),

- self-confidence (attained by quality support for navigation and orientation),

- control (attained by a well-designed interface).

The same authors also accentuate curiosity (ibid., p. 25), because sudden visual and audio effects induce sensory curiosity and attract attention, thus elevating motivation.

Jones, Issroff, Scanlon, Clough and McAndrew (2006, pp. 251-252) accentuate the motivational potential of mobile devices as a means of informal learning and propose six reasons why mobile learning might be motivating: freedom, ownership, communication, fun, context and continuity. Freedom is the ability to freely define tasks and to relate activities to the learners' goals; ownership, a key motivational factor, gives users a very strong sense of control; communication enables collaborative activities; fun is a key characteristic of the use of mobile devices among young people; mobile devices can be used to find information in the appropriate context; and continuity permits learners to transport information from one context to another. In a later paper Jones and Issroff (2007, pp. 248-249) only slightly modified the list as: control, ownership, learning-in-context, continuity between contexts, fun, and communication. Control implies "control over [learners'] own goals" (ibid.) and is connected to freedom in the above-mentioned way: ownership is further clarified as referring to ownership of the learning or of learning products, as well as "to physical ownership of the devices and their personal nature" (ibid.). Li, Lee, Wong, Yau and Wong (2017) conclude, "instead of enhancing motivation in general, mobile learning may improve one or more aspects of motivation. In this regard, the design of mobile learning activities could have more specific objectives in relation to motivating students to learn" (p. 267).

PSIQUE • e-ISSN 2183 - 4806 • Volume XV • Issue Fascículo 1 • 1st January Janeiro-30th June Junho 2019 
Potencial motivacional das aplicações móveis de aprendizagem de línguas estrangeiras duolingo e memrise e o seu uso entre os estudantes universitários na croácia

There is a rich body of research dealing with the use of ICT among school teachers (Wu, 2014; Zervas, Chatzistavrianos, Sampson et al., 2014; Light $\&$ Pierson, 2014; Brigas, 2016), while research into the ICT and its use in foreign language teaching and learning is rarer, particularly in regard with mobile language learning applications. Researchers agree that using ICT in general while teaching foreign languages helps to create an interactive and authentic learning environment (Li \& Walsh, 2011; Cajkler \& Addelman, 2012; Halvorsen, 2016). However Stockwell $(2013$; 2016) points out that the use of mobile applications outside the classroom is limited to entertainment and that they are rarely used for learning, which is confirmed in a research by Rico, Naranjo, Delicado, Plaza and Dominguez (2014); they also found out that apps used to learn foreign languages were mostly limited to dictionaries and translators. When we speak of university level language learners, research has discovered that they prefer mobile apps to other forms of learning techniques for they allow them to learn and practice at their own leisure (Lai, 2017), just as proposed in the above-mentioned papers by Jones et al.

The mobile language learning applications dealt with in this paper, Duolingo and Memrise, use gamification in order to attract learners. According to Rico et al. (2014) gamification is the perfect tool to increase motivation and it therefore contributes to more positive learning outcomes; on the other hand Lewis (2017) states that gamification leads to an increased engagement as its main purpose is to make routine tasks more interesting. Duolingo, Memrise and similar applications are usually understood to be part of the mobile-assisted language learning (MALL) system, which is defined by McCarty, Obari and Sato (2017) as; "The formal or informal acquisition to some extent through study of exercise of a second or foreign language, utilizing handheld, portable, or wearable devices for the purpose of language learning" (p.4).

However, the referred applications can also be considered as part of language learning social network sites (LLSNSs) as understood by Chick (2015) since they are connected to a vast forum-like repository of questions, answers and general or specific language discussions. For instance, every single answer of Duolingo contains a link to a discussion in which professionals and amateurs explain why the answer is (or is not) correct, giving examples and suggesting further reading.

Both Duolingo and Memrise are free; Duolingo offers courses in 23 languages and Memrise in over 100, but Duolingo is more focused and is organized along a system of jumping-off points that allows students to choose a proper level ${ }^{1}$. Some research into the use of both Memrise and Duolingo has already been conducted: Walker (2015, p. 20) concludes that Memrise is "superior as a way of learning Latin vocabulary over the methods that students would otherwise self-select", and a research into the use of Memrise to learn Japanese conducted by Librenjak, Janjić and Kocijan (2016, p. 59) showed that those students who used Memrise completed the course with better grades and their average score was significantly higher. Botero and Questier (2016, p. 153) have found that the respondents' views of Duolingo were positive as an instructional method, motivation tool, promoter of self-directed learning and enabler of language skills practice items, however, only a small percentage of tracked students $(10 \%)$ managed to completely finish a Duolingo course, which demonstrates "the difficulty of learners to self-regulate when learning".

In Croatia today, English is almost universally taught in schools, with some German and Italian classes, from the first grade of primary school (age 6); as a second foreign language students from age 9 can choose from German, French, Italian, Spanish, and English (for those rare students that do not learn it yet). All participants in our research learned English in school and in college, and therefore, for the purpose of this research, they used Duolingo and Memrise to learn languages other than English.

\footnotetext{
${ }^{1}$ Duolingo offers a total of 25 levels in languages like French (373 lessons) or Spanish (317 lessons). Memrise offers a total of 7 levels in the French course, where Level 1 in French consists of 84 lessons.

Memrise levels 1-3 equate to A1 level, 4-6 to A2 level, and 7 to B1 level of Common European

Framework of Reference for Languages (CEFR).
} 


\section{The description of the study}

This section begins with the description of the aims of this research study. It continues with the authors' starting hypotheses and an explanation how they were grounded. The justification of the hypotheses is followed by a detailed description of the participants, the instrument and the procedure of the research.

\subsection{The aim of the study}

The aims of the study presented below were the following:

a) to explore students' interests in FL learning and ICT technology as well as their achievement in FL learning in form of school grades;

b) to see what Croatian university students think about the motivational potential of mobile foreign language learning applications Duolingo and Memrise;

c) to see if there are any differences between students studying to become foreign language teachers and students studying to become nursery or primary school teachers of core subjects.

\subsection{Starting Hypotheses and Their Justification}

The starting points for the authors were the following six hypotheses: learning

H1 - Croatian university students studying to become primary school teachers are interested in FL

H2 - Croatian university students studying to become primary school teachers are interested in ICT technology

H3 - Croatian university students studying to become primary school teachers show high achievement in FL learning in forms of school grades

H4 - Croatian university students studying to become primary school teachers will see various aspects of motivational potential of FL learning by means of online apps for FL learning

H5 - Vast majority of students studying to become nursery or primary school teachers of core subjects and students studying to become primary school teachers of EFL and core subjects will not think that it is possible to successfully learn a FL only by means of online apps

H6 - Of all the tested variables there will be statistically significant difference in interest in FL learning and in the achievement in FL learning between students studying to become nursery or primary school teachers of core subjects and students studying to become primary school teachers of EFL and core subjects

The authors based their first and their third hypotheses on the popularity of FL learning and relatively high general achievement in FL learning compared to the popularity of FLs and familiarity with FLs in other countries.

The second and the fourth hypotheses were grounded on the popularity of ICT technology and smart phones among the Croatian youth.

The authors thought it would be quite natural that prospective foreign language teachers would be more interested in FL learning and that their grades would be higher than of the students that were not expected to teach that subject in the future (H6), but they did not think that any of the two tested groups would be more inclined towards ICT technology and see either higher or smaller potential for successful FL learning (H5).

\subsection{Participants}

Research for this current study was carried out on a sample of 116 students from the Faculty of Teacher Education of the University of Zagreb (Croatia) studying to become either nursery school teachers 
Potencial motivacional das aplicações móveis de aprendizagem de línguas estrangeiras duolingo e memrise e o seu uso entre os estudantes universitários na croácia

(29 students) or primary school teachers of core subjects (39 students) or primary school teachers of core subjects and primary school teachers of English as a foreign language (48 students) ${ }^{2}$. By the end of their formal education at the university nursery school teachers and primary school teachers of core subjects are supposed to reach B1 whereas teachers of core subjects and primary school teachers of English as a foreign language should reach $\mathrm{C} 1$ level of knowledge of English according to the Common European Framework of Reference for Languages: Learning, Teaching, Evaluation (CEFR).

For the purpose of this study the students in the sample were divided into two groups:

a) The first included students studying to become nursery school teachers and primary school teachers of core subjects (68 students)

b) The second one consisted of students studying to become primary school teachers of foreign languages (48 students).

The reason for this division was as follows: the former students had only been learning foreign languages for their own benefit whereas the latter were being trained to become professionals who would be teaching foreign languages.

Five respondents in our sample (4.3\%) were men, and 111 (95.7\%) were women ${ }^{3}$. At the time of data collection, they were all between 19 and 25 years of age. During the experiment over three quarters of the students in the sample (78.4\%) used their smart phones to learn foreign languages for the purpose of this research study.

All the data in this survey were collected between mid-December 2017 and during the first week of January 2018.

\subsection{Instrument and procedure}

The authors constructed an online questionnaire and posted it on the Internet ${ }^{4}$. It contained 35 questions but only and 12 of them were analyzed for the purpose of this research study. The majority of questions used a 5-point Likert scale. On five questions students were asked to write their own comments and three were multiple-choice. There were three additional multiple-choice questions about students' biodata.

The analysis in this paper looks into students' motivational factors. They can be divided into two groups: students' general motivation for FL learning and ICT technology and their achievement in FL learning. The first group thus included: students interest in students' interest in FL learning (item: "rate your interest in learning foreign languages"); students' interest in ICT technology (item: "Rate your general interest in ICT technology"); students' average grade in their first FL (item: "What was your average grade in your first foreign language in your previous education").

All the other analyzed items in the second group with one exception were variables associated with the motivational aspects of FL learning by means of online applications.

The exceptional variable in this group was a question that was concerned about students' opinion about the possibility of successful learning of a FL only by means of one or more of tested online apps (item: “...I think that I could learn a FL only by using one or more of the tested online apps").

\footnotetext{
${ }^{2}$ N.B. It seems that even many foreign scholars are unfamiliar with the structure of Croatian primary school and are usually surprised to hear that it lasts eight years. Therefore, it might be advisable that the following explanation should be given at this point: Pupils attending grades 1-4 are taught all the subjects by one teacher qualified to teach all the six core subjects: Croatian, Mathematics, Science, Physical Education, Arts and Music. Foreign languages and Religion in Grades 1-4 are taught by teachers qualified for those subjects. In grades 5-8 each subject is taught by a qualified teacher for that subject.

${ }^{3}$ It should also be noted here that female participants were not overrepresented as for over half the century more than $90 \%$ of the primary school teachers have been women.

${ }^{4}$ https://goo.gl/forms/Dw4bhVZlI9rCl68S2
} 


\section{Results and assessment}

Bearing in mind the starting hypotheses and taking into the consideration the aims of the study, the analysis of the results is subdivided into three subsections.

\subsection{Students' general motivation for FL learning and ICT technology and their achievement in FL learning.}

The first aim of this paper was to explore students' interests in FL learning and ICT technology as well as their achievement in FL learning in the form of school grades. The results for these three variables are separately presented below. They are analyzed through the results of the mean values as the most important measure of central tendency and through the length of bars for each of the five multiple-choice options in the graphical illustrations representing one questionnaire item.

\section{a) Students' interest in FL learning}

It can be seen from the results of the first variable in this subdivision presented in Table 1 that the mean value for this variable is very high. It is 4.23 with a standard deviation of 0.78 . The lengths of bars presented in Figure 1 show a very high tendency towards a very strong interested in FL learning. The highest number of students (49) or $42.2 \%$ of the surveyed students circled the value 5 indicating the strongest interest in FL learning. The value 4 is almost equally high (48 students or $41.4 \%$ ), followed by a very high gap between values 4 and 3. The lengths of bars as well as the numbers of students and their percentages show that three times less students opted for the neutral value 3 than for values of positive interest. Only three students or $2.6 \%$ indicated low interest. It is also important to note that there was no single student in the sample who is not interested in FL at all. All these numbers and percentages of students and the mean value show that Croatian university students studying to become primary school teachers are interested in FL learning and it can be concluded that the thirst starting hypothesis was confirmed by the results in this research study.

\section{Tabela 1}

Student's interest in FL learning

\begin{tabular}{c|c|c}
\hline Value & Number of students & Percentage of students \\
\hline 1 & 0 & 0 \\
\hline 2 & 3 & 2.6 \\
\hline 3 & 16 & 13.8 \\
\hline 4 & 48 & 41.4 \\
\hline 5 & 49 & 42.2 \\
\hline
\end{tabular}

Mean value $\quad 4.23$

St. dev. $\quad 0.78$


Potencial motivacional das aplicações móveis de aprendizagem de línguas estrangeiras duolingo e memrise e o seu uso entre os estudantes universitários na croácia

\section{Figure 1}

\section{Student's interests in FL learning}

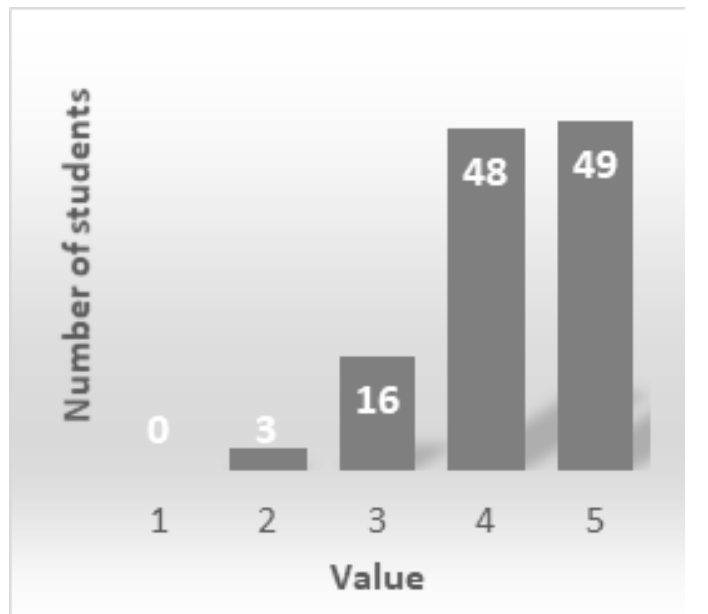

b) Students' interest in ICT technology

With their second hypothesis, the authors assumed that Croatian university students studying to become primary school teachers are interested in ICT technology. The results of the analysis of this second variable also confirmed correctness of the second hypothesis as the mean value is 3.79 , whereby the standard deviation is 0.85 (seen Table 2). It should be noted that the mean for this variable is lower than the mean for the first, thus indicating students' higher interest in FL learning than in ICT technology. The clue for this lower interest might be lying in the fact that the highest number of the students opted for value 4. The bar representing this value (see Table 2 and Figure 2) is more than three times higher than the bar representing the highest value 5 (value $4-63$ students or $54.3 \%$; value $5-20$ students or $17.2 \%$ ). It the previous variable most students opted for the highest value. One fifth of the students in the sample were indecisive in this variable. About $8 \%$ showed low interest and only one student showed total lack of interest.

\section{Tabela 2}

Student's interest in ICT technology

\begin{tabular}{c|c|c}
\hline Value & Number of students & Percentage of students \\
\hline 1 & 1 & 0.9 \\
\hline 2 & 9 & 7.8 \\
\hline 3 & 23 & 19.8 \\
\hline 4 & 63 & 54.3 \\
\hline 5 & 20 & 17.2 \\
\hline Mean value & 3.79 & \\
\hline St. dev. & & \\
\hline
\end{tabular}




\section{Graphic 2}

\section{Student's interests in ICT technology}

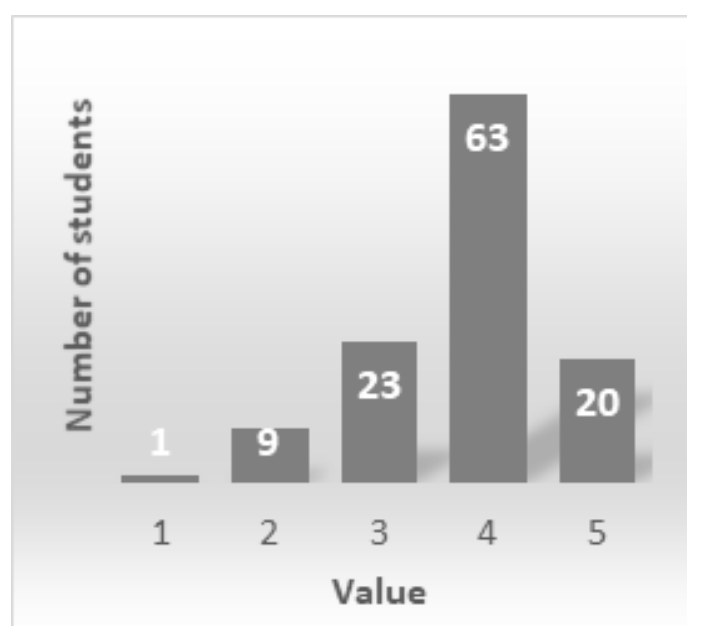

c) Students average grade in their first FL

Students' high interest in FL learning might have also contributed to a very high students' achievement in their first FL in the form of grades. It can be seen from the results of this variable that the third hypothesis H3 was also confirmed - Croatian university students studying to become primary school teachers show high achievement in FL learning in forms of school grades. This can be most easily seen from the mean value (seen Table 3), which is 4.41 and the standard deviation for this variable is 0.66. (The highest achievement in Croatian primary and secondary schools as well as at the college and university level is marked with grade 5 or "excellent" and the lowest grade is 1 or "insufficient" which stands for fail. Other grades are grade 4 or "very good"; grade 3 or "average" and grade 2 or "sufficient"). The lengths of bars (see Figure 3) illustrate a very strong tendency towards high achievement. Almost half of the surveyed students (57 students out of the total of 116, which is 49.1\%) had the highest possible final grade in their first foreign language. Additional 50 students or $43.1 \%$ had the second-best grade 4 . There were eight students (6.9\%) with grade 3 or "average" and only one student whose achievement in the first FL was received grade 2 or "sufficient".

\section{Tabela 3}

Students average grade in their first $F L$

\begin{tabular}{c|c|c}
\hline Value & Number of students & Percentage of students \\
\hline 1 & 0 & 0 \\
\hline 2 & 1 & 0.9 \\
\hline 3 & 8 & 6.9 \\
\hline 4 & 50 & 43.1 \\
\hline 5 & 57 & 49.1 \\
\hline Mean value & 4.41 & \multicolumn{2}{l}{} \\
\hline St.dev. & 0.66 &
\end{tabular}


Potencial motivacional das aplicações móveis de aprendizagem de línguas estrangeiras duolingo e memrise e o seu uso entre os estudantes universitários na croácia

\section{Figure 3}

\section{Students average grade in their first FL}

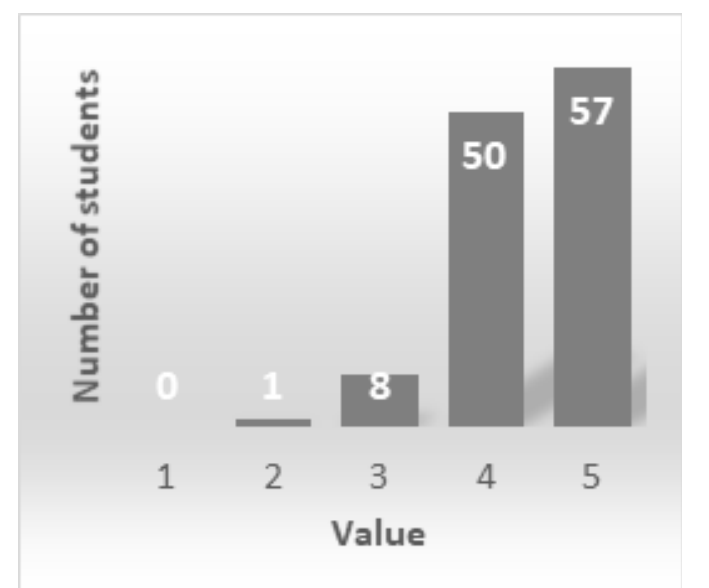

\subsection{Variables associated with the motivational aspects of FL learning by means of online applica- tions Memrise and Duolingo and students' opinion about the possibility of a possible successful learning of a FL only by means of one or more of tested online apps}

The second aim of this paper was to see what Croatian university students think about the motivational potential of mobile foreign language learning applications Duolingo and Memrise. The questionnaire contained seven items belonging to this subgroup. They are analysed in the same way as the three variables in the previous subdivision.

a) Students' opinion about the level of difficulty of FL learning by means of Memrise and Duolingo apps

It can be clearly seen from Table 4 and Figure 4 that vast majority of the surveyed students disagreed with the item that learning a FL with these apps is hard. There was no student that would have completely agreed with this statement. There were only seven students (6\% of the sample) who circled the value 4 . Less than $10 \%$ neither agreed nor disagreed with the statement. Almost $30 \%$ circled the value 2 and more than half of the students (64 students of the total of 116 or 55.2\%) absolutely disagreed as they circled value 1 . The mean value for this variable is 1.66 whereby the standard deviation is 0.88 . The analysis of this item leads us to conclusion that due to of the easiness of these mobile apps Croatian university students studying to become primary school teachers would not hesitate to use them to learn new foreign languages. 


\section{Tabela 4}

Students' opinion about the level of difficulty of FL learning by means of Memrise and Duolingo apps

\begin{tabular}{|c|c|c|}
\hline Value & Number of students & Percentage of students \\
\hline 1 & 64 & 55.2 \\
\hline 2 & 34 & 29.3 \\
\hline 3 & 11 & 9.5 \\
\hline 4 & 7 & 6 \\
\hline 5 & 0 & 0 \\
\hline \multicolumn{3}{|c|}{1.66} \\
\hline St. dev. & & \\
\hline
\end{tabular}

\section{Figure 4}

Students' opinion about the level of difficulty of FL learning by means of Memrise and Duolingo apps

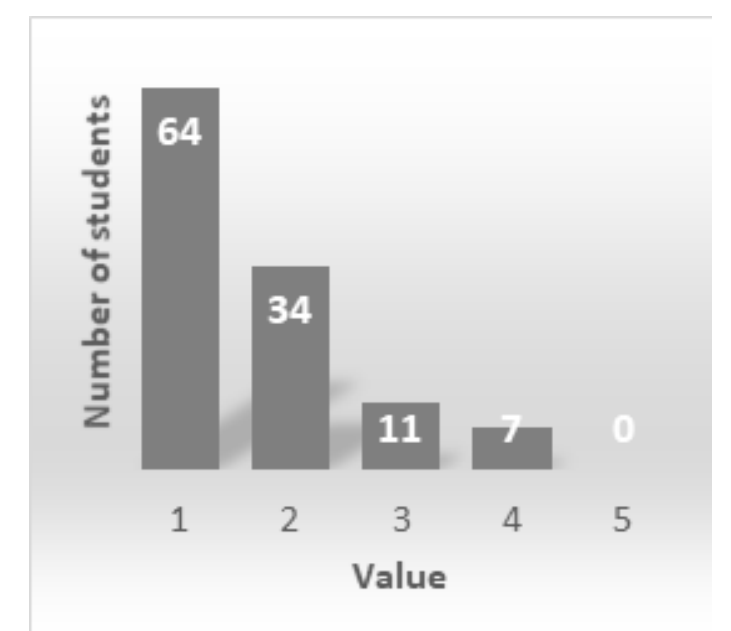


Potencial motivacional das aplicações móveis de aprendizagem de línguas estrangeiras duolingo e memrise e o seu uso entre os estudantes universitários na croácia

b) Comparison of FL learning with online apps and with "classical methods"

In the following question students were asked to compare the level of difficulty of learning a FL with online apps with the usual "classical methods". The mean value for that variable was 3.97 and the standard deviation was 0.98 (see table 5). This means that the majority of students think that learning a FL with online apps is easier than learning it "in a classical way". Only one student completely disagreed and less than $10 \%$ disagreed. $15.5 \%$ of the surveyed students neither agreed nor disagreed. It can be seen from Figure 6 that the highest bar is for value 4 as 46 students or almost $40 \%$ circled it. A little lower is the bar for value 5 . There were 40 students or $34.5 \%$ of the students who completely agreed with this statement. This leaves us with the thought that about three quarters of the surveyed students tend to regard these apps as a more convenient tool from the point of view of the easiness of learning.

\section{Tabela 5}

Comparison of FL learning with online apps and with "classical methods"

\begin{tabular}{|c|c|c|}
\hline Value & Number of students & Percentage of students \\
\hline 1 & 1 & 0.99 \\
\hline 2 & 11 & 9.5 \\
\hline 3 & 18 & 15.5 \\
\hline 4 & 46 & 39.7 \\
\hline 5 & 40 & 34.5 \\
\hline \multicolumn{3}{|l|}{ Mean value } \\
\hline St. dev. & & \\
\hline
\end{tabular}

\section{Figure 4}

\section{Comparison of FL learning with online apps and with "classical methods"}

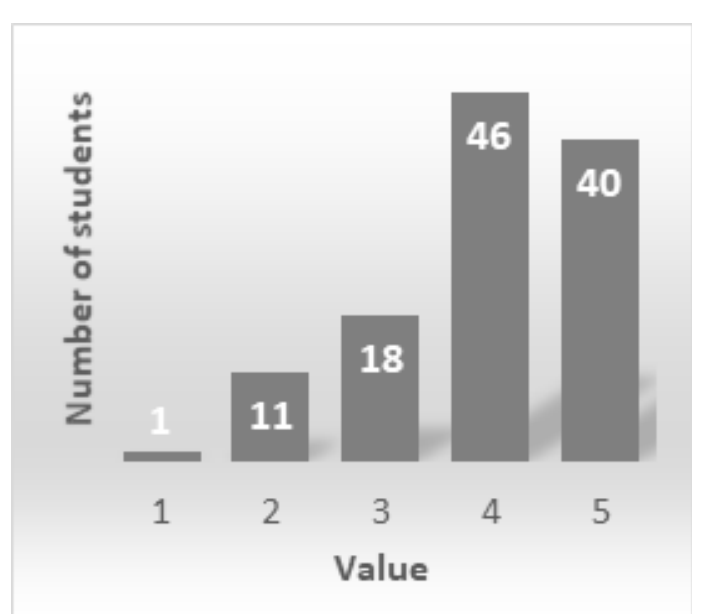


c) Students' Opinion about the Advantage of Apps resulting from of their Availability

The analysis of the results of the third item (see Table 6 and Figure 6) in this group reveals that the surveyed students see a very high potential of these online applications resulting from their availability. The mean value for this item is 4.66 (standard deviation - 0.99). About three quarters of the students in the sample (54 or 46.6 circled option 5 and 36 or $31 \%$ circled option 4 ) think that it is important for them that they can learn a FL by using these apps anytime and anywhere. 19 students (more than one eight) were indecisive and only about $6 \%$ did not see the advantage of these apps with regard of their availability.

\section{Tabela 6}

Students' opinion about the advantage of apps resulting from their availability

\begin{tabular}{c|c|c}
\hline Value & Number of students & Percentage of students \\
\hline 1 & 3 & 2.6 \\
\hline 2 & 4 & 3.4 \\
\hline 3 & 19 & 16.4 \\
\hline 4 & 36 & 31 \\
\hline 5 & 54 & 46.6 \\
\hline Mean value & 4.66 & \\
St. dev. & 0.99 & \\
\hline
\end{tabular}

\section{Figure 6}

\section{Students' opinion about the advantage of apps resulting from their availability}

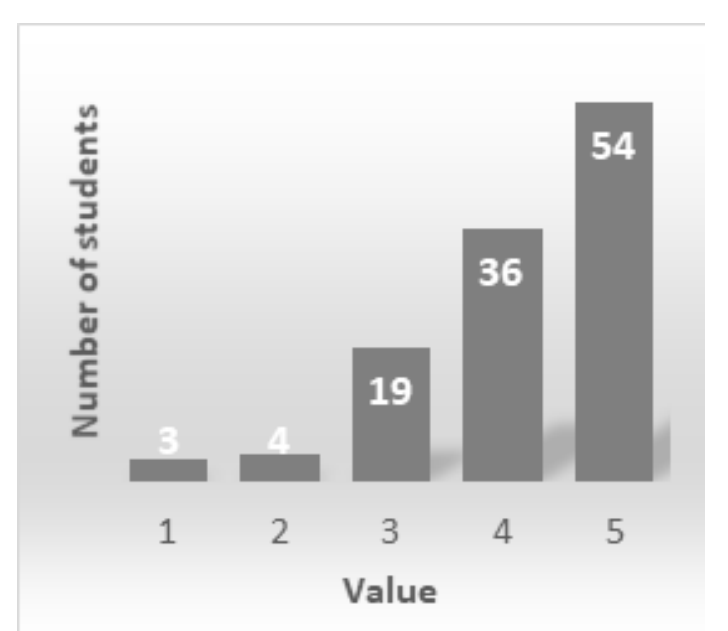


Potencial motivacional das aplicações móveis de aprendizagem de línguas estrangeiras duolingo e memrise e o seu uso entre os estudantes universitários na croácia

d) Students' opinion about the gamification of apps

Similar percentages of students, though not identical as in the previous variable, see an advantage of these mobile FL online learning apps because of their gamification (see table 7 and figure 7). This time roughly four fifths of the students in the sample (about $81 \%$ ) agree or strongly agree with this statement, as they circled value 4 or 5.12 students or roughly one tenth of the sample neither agree nor disagree with the statement that they like this kind of FL learning because they can follow their level of progress and get points and prizes like in a computer game. And about $8.6 \%$ of the sample (again almost one tenth of all the students) either disagree or strongly disagree with it. All these percentages resulted in a lower mean value than in the previous variable. It is 4.24 with the standard deviation of 0.98 .

\section{Tabela 7}

Students'opinion about the gamification of apps

\begin{tabular}{|c|c|c|}
\hline Value & Number of students & Percentage of students \\
\hline 1 & 1 & 0.86 \\
\hline 2 & 9 & 7.76 \\
\hline 3 & 12 & 10.35 \\
\hline 4 & 33 & 28.45 \\
\hline 5 & 61 & 52.59 \\
\hline \multicolumn{3}{|l|}{ Mean value } \\
\hline St. dev. & & \\
\hline
\end{tabular}

\section{Figure 7}

\section{Students' opinion about the gamification of apps}

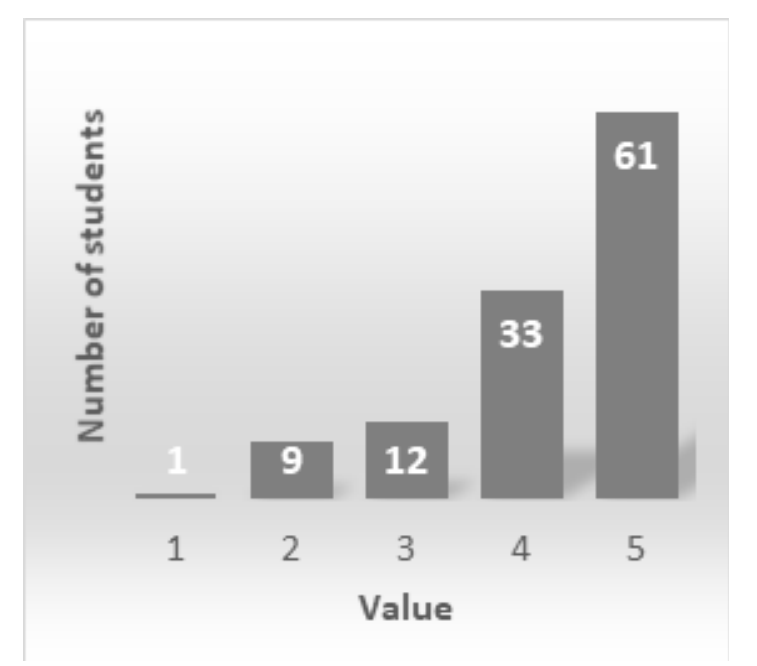

PSIQUE • e-ISSN 2183 - 4806 • Volume XV • Issue Fascículo 1 • 1st January Janeiro-30th June Junho 2019 
e) Students' opinion about how successfully they have mastered this kind of FL learning

One of the preconditions for effective learning by means of online apps is that the user has no technical problems and they can skilfully use it. All the data presented in Table 8 and Figure 8 below prove that this prerequisite has been met. The mean value of 4.34 (standard deviation -0.84 ) is very satisfying. This high value was achieved because $85 \%$ of the students had circled values 4 and 5 . It must not be overlooked that more than half of the students opted for value 5 meaning that they had completely mastered this kind of FL learning. One tenth was indecisive, three students (2.6\%) thought that their skills were poor and only one student was absolutely unsatisfied. All this leads us to conclusion that the overwhelming majority of the students in this sample think that they do not lack any necessary skills for successful FL learning by means of these two online applications.

\section{Tabela 8}

Students' opinion about how successfully they have mastered this kind of FL learning

\begin{tabular}{c|c|c}
\hline Value & Number of students & Percentage of students \\
\hline 1 & 1 & 0.9 \\
\hline 2 & 3 & 2.6 \\
\hline 3 & 13 & 11.2 \\
\hline 4 & 38 & 32.8 \\
\hline 5 & 61 & 52.6 \\
\hline Mean value & 4.34 & \\
\hline \multicolumn{3}{l}{ St. dev. } \\
\hline
\end{tabular}

\section{Figure 8}

Students' opinion about how successfully they have mastered this kind of FL learning

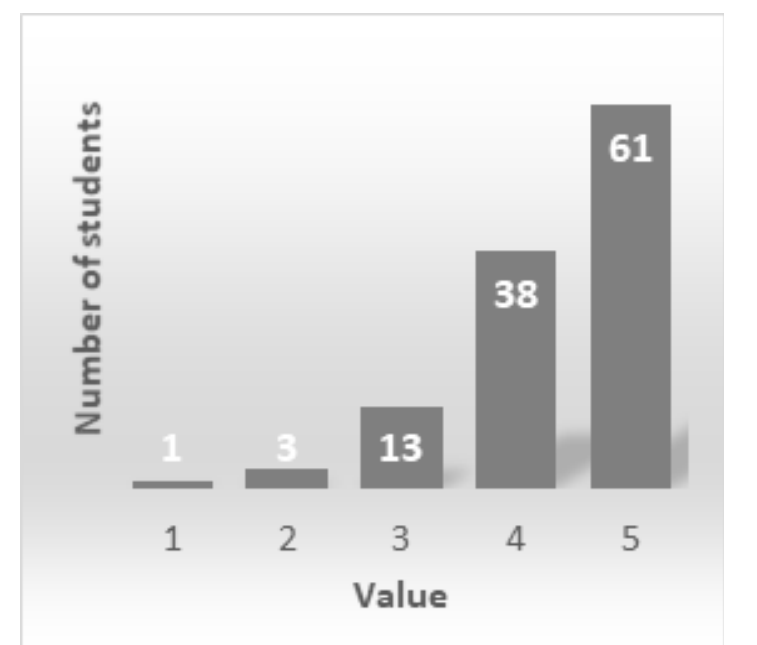

PSIQUE • e-ISSN 2183 - 4806 • Volume XV • Issue Fascículo 1 • 1st January Janeiro-30th June Junho 2019 
Potencial motivacional das aplicações móveis de aprendizagem de línguas estrangeiras duolingo e memrise e o seu uso entre os estudantes universitários na croácia

f) Students' opinion about the amusing character of FL learning by means of mobile apps

Is is usually widely thought that motivation can be increased and that the advancement in learning can be enhanced whenever learning has an amusing character. A very high mean value (4.45) seems to be an indication that this goal has been achieved. It is important to note that there was no single student that was completely unsatisfied with this aspect of Duolingo and Memrise applications (see Table 9 and Figure 9). The highest number of the surveyed students (68 or 58\%) chose value 5 showing that almost three fifths of them are completely satisfied with the amusement provided by the two tested applications during the FL learning process. The value 4 was chosen by one third of the students, leaving less than one tenth of the students among those that were either indecisive or poorly satisfied with this aspect of the apps.

\section{Tabela 9}

Students' opinion about the amusing character of FL learning by means of mobile apps

\begin{tabular}{c|c|c}
\hline Value & Number of students & Percentage of students \\
\hline 1 & 0 & 0 \\
\hline 2 & 3 & 2.6 \\
\hline 3 & 6 & 5.2 \\
\hline 4 & 39 & 33.6 \\
\hline 5 & 68 & 58.6 \\
\hline
\end{tabular}

Mean value $\quad 4.45$

St. dev. $\quad 0.79$

\section{Figure 9}

\section{Students' opinion about the amusing character of FL learning by means of mobile apps}

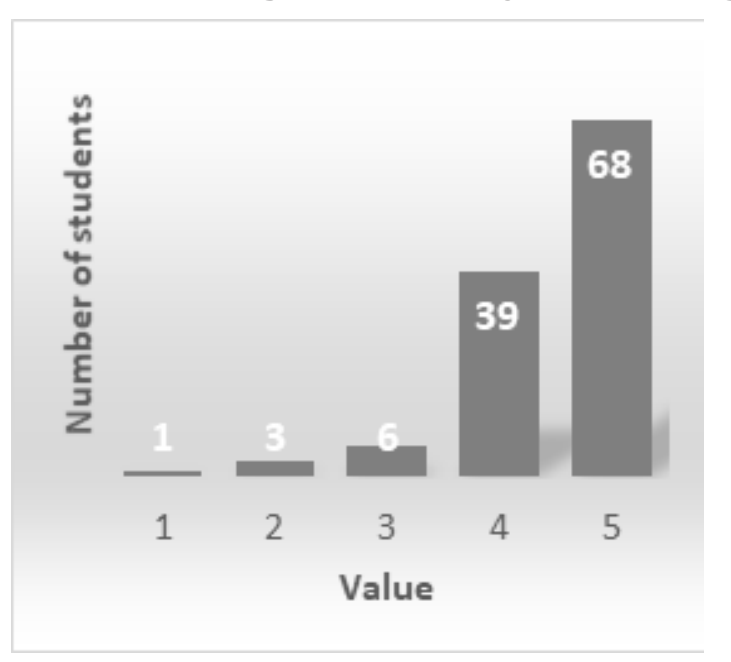


The results of the first six variables presented above in this subgroup show that Croatian university students studying to become primary school teachers see various aspects of motivational potential of FL learning by means of online apps for FL learning. They think that FL learning by means of these apps is not difficult, that it can be easier than usual learning by means of the so-called "classical methods" and that they have successfully mastered it. The same sample of students sees important advantages of Duolingo and Memrise applications due to their availability, gamification and amusing character. All these results show that the fourth hypothesis has been confirmed.

g) Students' opinion about a possible successful learning of a FL only by means of one or more tested Online Apps

There was one additional variable in this subgroup. It was the time that was put into the questionnaire to give an answer to the fifth starting hypothesis. The students were asked to answer the question whether they think it was possible or not to successfully learn a FL only by means of one or more tested online apps. The authors of this paper were sceptical about the possibility that the majority of the surveyed students would agree with the statement. They thought that there would be more students who think that having a teacher is a prerequisite for a successful FL learning. The results of this variable (see Table 10 and Figure 10) do not give evidence for this hypothesis as a little more than half of the students circled values 4 and 5 (value $4-42$ students or $36.2 \%$; value $5-28$ students or $24.1 \%$ ). The mean value is 3.62. Less than one fourth of the sample (26 students or 22.4\%) neither agree nor disagree with the statement. Less than one fifth of the sample either disagree (13 students or 11.2\%) or strongly disagree (seven students or 6\%).

\section{Tabela 10}

Students' Opinion about Successful Learning a FL Only by Means of One or More Tested Online Apps

\begin{tabular}{|c|c|c|}
\hline Value & Number of students & Percentage of students \\
\hline 1 & 7 & 6 \\
\hline 2 & 13 & 11.2 \\
\hline 3 & 26 & 22.4 \\
\hline 4 & 42 & 36.2 \\
\hline 5 & 28 & 24.1 \\
\hline \multicolumn{3}{|c|}{3.62} \\
\hline St. dev. & & \\
\hline
\end{tabular}


Potencial motivacional das aplicações móveis de aprendizagem de línguas estrangeiras duolingo e memrise e o seu uso entre os estudantes universitários na croácia

\section{Figure 10}

Students' Opinion about Successful Learning a FL Only by Means of One or More Tested Online Apps

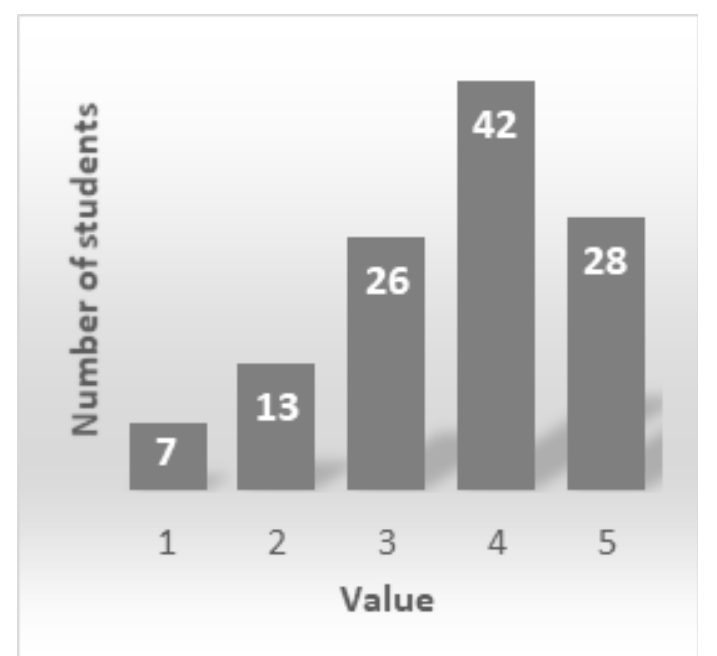

\subsection{Differences between Prospective Primary School Teachers of EFL and Other Teachers}

The third aim was to see if there are any differences between students studying to become foreign language teachers and students studying to become nursery or primary school teachers of core subjects.

Statistically significant differences were only found in the differences between means in students' interest in FL learning and in the achievement in FL learning in form of school grades for that subject

a) t-test results: Students Interest in FL Learning

It can be seen that prospective EFL teachers were more interested in FL learning. The mean was 4.03 for general teachers and 4.52 for future EFL teachers (see Table 11). t-test results have shown that students studying to become foreign language teachers and students studying to become nursery or primary school teachers of core subjects belong to two different populations (t-3.52; $<<0.01)$.

\section{Tabela 11}

T-test results: Students Interest in FL Learning

\begin{tabular}{l|c|c|c|c|c|} 
& \multicolumn{1}{c}{ N } & Mean & SD & $t$ & $p$ \\
\hline $\begin{array}{l}\text { Prospective Nursery and } \\
\text { Primary School Teachers of } \\
\text { Core Subjects }\end{array}$ & 68 & 4.03 & 0.79 & 3.52 & 0.01 \\
$\begin{array}{l}\text { Prospective Primary School } \\
\begin{array}{l}\text { Teachers of EFL and Cores } \\
\text { Subjects }\end{array}\end{array}$ & 48 & 4.52 & 0.68 & & \\
\hline
\end{tabular}


b) t-Test Results: Students School Grades in Their First FL

It can be seen that prospective EFL teachers had higher school grades in their first foreign language. The mean was 4.29 for general teachers and 4.56 for future EFL teachers. t-test results have again shown that students studying to become foreign language teachers and students studying to become nursery or primary school teachers of core subjects belong to two different populations $(\mathrm{t}-2.3 ; \mathrm{p}<0.01)$.

\section{Tabela 12}

t- Test results: Students School Grades in Their First FL

\begin{tabular}{l|c|c|c|c|c|}
\hline & N & \multicolumn{1}{c}{ Mean } & \multicolumn{1}{c|}{ SD } & $t$ & $p$ \\
\hline $\begin{array}{l}\text { Prospective Nursery and } \\
\text { Primary School Teachers of } \\
\text { Core Subjects }\end{array}$ & 68 & 4.29 & 0.71 & 2.3 & 0.05 \\
\hline $\begin{array}{l}\text { Prospective Primary School } \\
\begin{array}{l}\text { Teachers of EFL and Cores } \\
\text { Subjects }\end{array}\end{array}$ & 48 & 4.56 & 0.54 & & \\
\hline
\end{tabular}

t-test results for all the other tested results have not been statistically significant. These results have confirmed the sixth starting hypothesis. Of all the tested variables for the purpose of this research study there are statistically significant differences between students studying to become nursery or primary school teachers of core subjects and students studying to become primary school teachers of EFL and core subjects only $\mathrm{n}$ two variables: interest in FL learning and the achievement in FL learning.

\section{Conclusion and implications for future research studies}

Five of six starting hypotheses have been confirmed by the results of this research study:

H1 - Croatian university students studying to become primary school teachers are interested in FL learning

H2 - Croatian university students studying to become primary school teachers are interested in ICT technology

H3 - Croatian university students studying to become primary school teachers show high achievement in FL learning in forms of school grades

H4 - Croatian university students studying to become primary school teachers see various aspects of motivational potential of FL learning by means of online apps for FL learning

H6 - Of all the tested variables for the purpose of this research study there are statistically significant differences between students studying to become nursery or primary school teachers of core subjects and students studying to become primary school teachers of EFL and core subjectsnly only n two variables: interest in FL learning and the achievement in FL learning.

The results have not confirmed the fifth starting hypothesis. Its text was as follows: "H5 - Vast majority of students studying to become nursery or primary school teachers of core subjects and students studying to become primary school teachers of EFL and core subjects do not think it is possible to successfully learn a FL only by means of online apps." According to the results of this research study a vast majority of students studying to become nursery or primary school teachers of core subjects and students studying to become primary school teachers of EFL and core subjects do think it is possible to successfully learn a 
Potencial motivacional das aplicações móveis de aprendizagem de línguas estrangeiras duolingo e memrise e o seu uso entre os estudantes universitários na croácia

FL only by means of online apps. This means that the percentage of the surveyed students from the Faculty of Teacher Education at the University of Zagreb who are positively inclined towards a possibility of a successful FL learning only by using online maps is higher than it has been thought by the authors of this paper. This generation of university students seems to be more positively inclined towards ICT technology and sees its high potential for FL learning.

The authors think that there is a need for a follow-up research study. It would have to encompass other mobile learning applications. Its results would show whether the high motivational factor expressed by respondents in this study would remain constant in spite of the repetitive nature of exercises present in the said applications. 


\section{References}

Alessi, S. M., \& Trollip, S. R. (2004). Multimedia for Learning: Methods and Development. London/New York: Pearson

Botero, G. G., \& Questier, F. (2016). What Students Think and What They Actually Do in a Mobile Assisted Language Learning Context: New Insights for Self-directed Language Learning in Higher Education. In S. Papadina-Sophocleous, L. Bradley and S. Thouesny, (eds.), CALL Communities and Culture - Short Papers from EUROCALL 2016 (pp. 150-154). Dublin: Research-publishing.net

Brigas, C. (2016). Use of ICT in School Context: Pupils', Parents' and Teachers' Perceptions. In M. J. Marcellino et al. (eds.), ICT in Education: Multiple and Inclusive Perspectives (pp. 97-114). Cham: Springer

Cajkler, W., \& Addelman, R. (2012). The Practice of Foreign Language Teaching. New York/London: Routledge

Chick, A. (2015). Recreational Language Learning and Digital Practices: Positioning and Repositioning. In R. H. Jones, A. Chick and C. A. Hafner (eds.), Discourse and Digital Practices. Doing Discourse Analysis in the Digital Age. Oxon/New York: Routledge

Halvorsen, A. D. (2016). Divergent Teacher Viewpoints of Technology Integration in the Language Classroom. In L. Chin-Hsi et al. (eds.), Preparing Foreign Language Teachers for Next-Generation Education (pp. 130-152). Hershey: IGI Global

Jones, A., Issroff, K., Scanlon, E., Clough, G., McAndrew, P., \& Blake, C. (2006). Using mobile devices for learning in informal settings: is it motivating? In IADIS International Conference on Mobile Learning (pp. 251-255). Dublin: IADIS Press

Jones, A., \& Issroff, K. (2007). Motivation and mobile devices: exploring the role of appropriation and coping strategies. ALT-J, 15(3), 247-258.

Lai, C. (2017). Autonomous Language Learning with Technology: Beyond the Classroom, London: Bloomsbury Publishing

Lewis, G. (2017). Learning Technology. London: Oxford University Press

Li, K. C., Lee, L. Y-K., Wong, S-L., Yau, I. S-Y., \& Wong, B. T-M. (2017). Effects of Mobile Apps on Learning Motivation and Study Performance. In S. Cheung, L. Kwok, W. Ma, L-K. Lee, H. Yang (eds.), Blended Learning. New Challenges and Innovative Practices (pp. 259-272). Cham: Springer

Li, L., \& Walsh, S. (2011). ‘Seeing Is Believing': Looking at EFL Teachers’ Beliefs through Classroom Interaction. Classroom Discourse, 2(1), 39-57

Librenjak, S., Janjić, M., \& Kocijan, K. (2016). Sustainable Vocabulary Acquisition in Japanese Classroom with the Help of Memrise. In Proceedings of IAC-GETL in Budapest 2016 (pp. 54-61). Prague: Czech Institute of Academic Education z.s.

Light, D., \& Pierson, E. (2014). Case Studies of Russian Educators Transforming Classroom Practices Through ICT-Rich School Environments. In R. Huang et al. (eds.), ICT in Education in Global Context: Emerging Trends Report 2013-2014 (pp. 47-65). Berlin-Heidelberg: Springer

McCarty, S., Obari, H., \& Sato, T. (2107). Implementing Mobile Language Learning Technologies in Japan. Singapore: Springer

Rico, M., Naranjo, M. J., Delicado, G., Plaza, N., \& Dominguez, E. (2014). Let's Move: Mobile Learning for Motivation in Language Acquisition. In Pixel (ed.), ICT for Language Learning, 7th Conference Edition (pp. 86-90). Padova: Webster srl

Stockwell, G., \& Hubbard, P. (2013). Some emerging principles for mobile-assisted language learning. Monterey, CA: The International Research Foundation for English Language Education, pp. 1-15. Retrieved from http://www.tirfonline.org/english-in-the-workforce/mobile-assisted-languagelearning (Accessed: 1 December 2017)

Stockwell, G. (2016). Mobile Language Learning. In F. Farr and L. Murray (eds.), The Routledge Handbook of Language Learning and Technology. Routledge: New York/London 
Potencial motivacional das aplicações móveis de aprendizagem de línguas estrangeiras duolingo e memrise e o seu uso entre os estudantes universitários na croácia

Walker, L. (2015). The Impact of Using Memrise on Student Perceptions of Learning Latin Vocabulary and on Long-term Memory of Words. Journal of Classics Teaching, 16(32), 14-20

Wu, D. (2014). An Introduction to ICT in Education in China. In: Huang, R., et al. (eds.), ICT in Education in Global Context: Emerging Trends Report 2013-2014. (pp. 65-84). Berlin-Heidelberg: Springer

Zervas, P., Chatzistavrianos, K., \& Sampson, D. G. (2014). Towards Modelling Teachers' ICT Competence Profile in Europe. In R. Huang et al. (eds.), ICT in Education in Global Context: Emerging Trends Report 2013-2014 (pp. 163-184). Berlin-Heidelberg: Springer 